\title{
A Worldwide Survey on the Use of Social Networking in Higher Education: A Teacher's Perspective
}

\author{
Silvia Gaftandzhieva, University of Plovdiv "Paisii Hilendarski”, Bulgaria \\ Rositsa Doneva, University of Plovdiv “Paisii Hilendarski”, Bulgaria
}

\begin{abstract}
Social networking is becoming a more powerful tool for students for communication, information sharing, and discussions. This paper presents a study, based on a survey questionnaire, which aims to investigate to what extent and for what purposes teachers from different countries from all over the world use social networking in their teaching practice. The attitude towards the use of social networking in higher education in general is examined. The study is intended to seek dependences between the answers related to the above issues and different teachers' characteristics, on the point of view if the teachers are well informed about social networking sites, or whether they participate in interest groups or research related to social networking and higher education. Finally, summarized results of the survey are presented, depending on the continent where the countries of the participants are located.
\end{abstract}

\section{KEYWORDS}

Higher Education, Social Media, Social Networking, Teaching Practice, Worldwide Survey

\section{INTRODUCTION}

Students in the 21st century (referred to as the digital generation, digital natives) are growing up constantly connected to the world around them through smartphones, tablets, and computers. Marc Prensky (Prensky, 2001) defines the term "digital native" and applies it to a new group of students enrolling in educational establishments referring to the young generation as "native speakers" of the digital language of computers, videos, video games, social media and other sites on the internet.

Students from the digital generation thrive on creative and engaging activities, varied sources of information and a more energetic environment. Teachers are faced with the challenge of understanding how they learn, how they communicate and interact with the world in order to meet the needs of today's students and to teach more effectively. Today social networking as a powerful tool for users for communication, information sharing and discussions on various topics responds to those needs.

The wide academic and research interest in the use of social networking for educational purposes in higher education is the natural result of constantly growing popularity of social networking according to a worldwide survey, approximately 2 billion internet users are using social networks today (Statista'2018).

According to Pearson (Seaman \& Tinti-Kane, 2013, 5 p.), a learning company that promotes the effective use of technology, "A majority of faculty now use social media in a professional context (any 
aspect of their profession outside of teaching). Use of social media for teaching purposes has lagged even more, but like the other patterns of use, it has increased every year. The number of faculty who use social media in the classroom still does not represent a majority, but teaching use continues its steady year-to-year growth. Faculty are sophisticated consumers of social media. In general, they see considerable potential in the application of social media and technology to their teaching, but not without a number of serious barriers".

In recent years there has been extensive academic and research interest into the use of social networking for educational purposes related to:

- $\quad$ ways to enhance the teaching and learning process (Acharya, Patel, \& Jethava, 2013);

- introversion and collaborative learning (Voorn \& Kommers, 2013);

- the use of social networking sites as a learning management system (Wang, Woo, Quek, Yang \& Liu, 2011);

- information reservoirs (Kropf, 2013);

- $\quad$ support of student involvement (Arquero \& Romero-Frías, 2013);

- $\quad$ the learning communitites and peer-reviews for MOOCS (Rothkrantz, 2015);

- advertising campaigns of courses (Zancanaro \& Domingues, 2018)

- $\quad$ promotion of higher education institutions on social networks (Golubić \& Lasić-Lazić, 2012; Golubić, 2017).

A number of surveys have been conducted worldwide on the use of social networks by teachers and students aiming to investigate:

- the extent to which teachers use social networking sites to connect with students and parents, and as an education tool (Hendee, 2014);

- how many teachers in higher education institutions are using social media, and in what capacity (Faculty Focus, 2011);

- the use of social networking technologies in higher education - extent of use, benefits and skills learners acquire from the use of these technologies (Zanamwe, Rupere, \& Kufandirimbwa, 2013);

- $\quad$ the effects of social media use on collaborative learning (Mardikyan \& Bozanta, 2017);

- the personal and professional impacts of social media on teaching faculty (Moran, Seaman, \& Tinti-Kane, 2011);

- the effects of social media on academic performance of students in university (Kolan \& Dzandza, 2018);

- the influence of social networks on high school students' performance (Abu-Shanab \& AlTarawneh, 2015).

The results of these surveys show that teachers do not use social networking sites for communication with their students (Hendee, 2014; Faculty Focus, 2011; Somova, 2014) and during lessons (Hendee, 2014). Teachers use social networking sites to share information and resources with educators, to create professional learning communities and to connect with peers and colleagues (edWeb, 2009), to improve students' engagement in their course and their educational experience (Hendee, 2014; Mardikyan \& Bozanta, 2017; Rutherford, 2010; Rodriguez, 2011; Junco, Elavsky, $\&$ Heiberger, 2013). Most of these surveys are held within a university or country. Therefore, the summarised results do not allow us to draw conclusions about the attitude of teachers towards the use of social networks worldwide.

The paper presents the study on teachers' attitude towards the use of social networking sites (Facebook, Twitter, Google+, Bebo, Myspace, LinkedIn, etc.) in higher education in general. It describes the methodology, organization of the study and analyses of the results in accordance with the study objectives. The paper points to general conclusions about the latest trends in the use of 
social networking in higher education (which allows teachers to meet the needs of bachelor and master students).

\section{DESIGN OF THE STUDY}

The study aims to investigate the extent to which teachers in higher education all over the world use social networking sites in their teaching practice for different purposes on the basis of results from a survey.

The sub-goals of the study are to seek dependencies between the answers to the questions and the circumstances of teachers, such as:

- $\quad$ whether they are well informed about social networking sites;

- whether they participate in groups interested in the use of social networking for educational purposes;

- whether they are doing research related to the use of social networking in higher education;

- $\quad$ and the countries where the participants reside.

This section describes briefly the process of data collection and analysis, in order to contextualise the sections that follow. The study's methodology is based on an empirical approach - an exploratory survey using questionnaire for data collection. The questionnaire has been used to conduct a survey on the attitude towards the use of social networking in Bulgarian higher education (Doneva \& Gaftandzhieva, 2017). The questionnaire has been validated by experts in the field. After running the pilot test, Principal Components Analysis was used to identify underlying components that are being measured by questions. The internal consistency of questions that load onto the same factors was calculated to ensure that survey answers are consistent. On the final step of the validation process the survey was revised on the basis of the information gathered from principal components analysis and internal consistency. 2 question that do not load into factors was removed. The final version contains 20 questions divided into three sections (see Appendix).

The questions in Section 1. Personal Information for participant (see Appendix) aim to determine the profile of respondents: gender, age, degree, title, university, country. This section contains a question about how aware participants are of social networking, to ensure the reliability of conclusions drawn from the analysis of the inquiry results. In order to examine teachers' attitude towards the use of social networking for educational purposes, the main part of the questionnaire includes two sections Opinion on the use of social networks in teaching practice (Section 2, see Appendix) and Opinion on the use of social networking for educational purposes in general (Section 3, see Appendix). Section 2 includes a list of 8 statements with numbers 8-15 (see Appendix) asking teachers about the use of social networking in their academic practice for difference purposes: formal use (for communication, consultation, discussions, organization, sharing of information (see Statements 8-10), during training (see Statements 11, 14, 15), for research (see Statements 12-13). Section 3 is a list of 3 statements about the use of social networking for educational purposes in general. Most of the statements in Section 2 and Section 3 are multiple choice. Teachers should state how far they agree with the statements on the 5-point Likert-type scale, where 1 means Strongly Disagree (SD), 2 is Disagree (D), 3 is Neutral $(\mathrm{N}), 4$ is Agree (A) and 5 is Strongly Agree (SA). There are open-ended questions for teachers at the end of these sections. This allows teachers to indicate how they use social networking in their teaching practice and why they consider that the use of social networks in education has a negative effect (if that is the case).

The questionnaire was sent by email to teachers working in higher education institutions. Around 100000 randomly selected teachers from all over the world were asked to participate in the study in the space of 6 months. Their e-mail addresses were retrieved from the public websites of 11997 
higher education institutions where they work. An email with an invitation to participate in the study was then sent to all of them.

The response rate was $19.98 \%$ (19 987 of all invited teachers) which is a good result for external surveys. Due to the fact that participants were randomly selected according to the information available on websites of higher education institutions, it is difficult to take into consideration the specific and local/contextual peculiarities. Therefore, the participants are treated as a group, meaning results are not analysed by country and subject domain, and country contextual differences have not been taken into consideration in the analysis.

Data analysis of the collected data includes two stages. In the first stage, the summarized answers to all questions are presented in tables and figures (see Survey Result). In the second stage, the summarized results are compared with results of other surveys and answers to research questions are given (see Findings and Discussions).

The following research questions were formulated in line with the stated sub-objective of the study:

- RQ1. Does the extent to which teachers use social networking sites depend on their information about them?

- RQ2. Does the extent to which teachers use social networking sites depend on their participation in groups interested in the use of social networking for educational purposes?

- RQ3. Does the extent to which teachers use social networking sites depend on their participation in research related to the use of social networking for educational purposes?

- $\quad$ RQ3. Does the extent to which teachers use social networking sites vary according to the continent where the countries of the participants are located?

To give answers to the research questions and to determine whether the dependencies formulated apply, a more detailed assessment of data collected has been made. The analyses made for RQ1 include calculation of the number/percentage of answers to other questions according to the answer given to Question 7. The analyses made for RQ2 and RQ3 include calculation of the number/percentage of answers to other questions according to the answer given to Question 7 and Statement 12, as well as a comparison of average scores to statements of teachers who answered positively or negatively to Question 7 and Statement 12. The analyses made for RQ4 include calculation of average scores of all statements (Statement 8-19)/sections (Section 2 and Section 3) given by teachers from the seven countries with the largest number of participants in the survey. The results of these analyses are presented in tables and figures.

\section{FINDINGS AND DISCUSSION}

\section{Respondents' Profile}

The analysis of the survey results is presented on the basis of valid responses of 19987 teachers from 75 countries around the world who participated in the survey. All countries with participants are marked with a certain color depending on the continent where they are located. Figure 1 presents the number of participants from each continent. 121 teachers did not answer the question about the country in which they work.

Out of the total number of teachers $49.75 \%$ are male and $55.25 \%$ are female. The largest group of teachers (28.34\%) are 55 or above, $26.75 \%$ of teachers are $45-54$ years old and $24.76 \%$ of teachers are 35-44 years old. The smallest groups of teachers are 25-34 years old (17.34\%) and below 25 years old $(2.81 \%)$. Half of the teachers have a Ph.D. degree (50.08\%) and D.Sc. degree (3.47\%). Table 1 presents a summary profile of respondents based on the gathered demographic and other personal data.

Most teachers are familiar with social networking $-65.49 \%$ answered Yes and $29.94 \%$ Yes/No to the question "Are you well informed about social networking (e.g. Facebook, Twitter, Google+, 
Figure 1. Number of participants by continents (Adopted from https://mapchart.net)

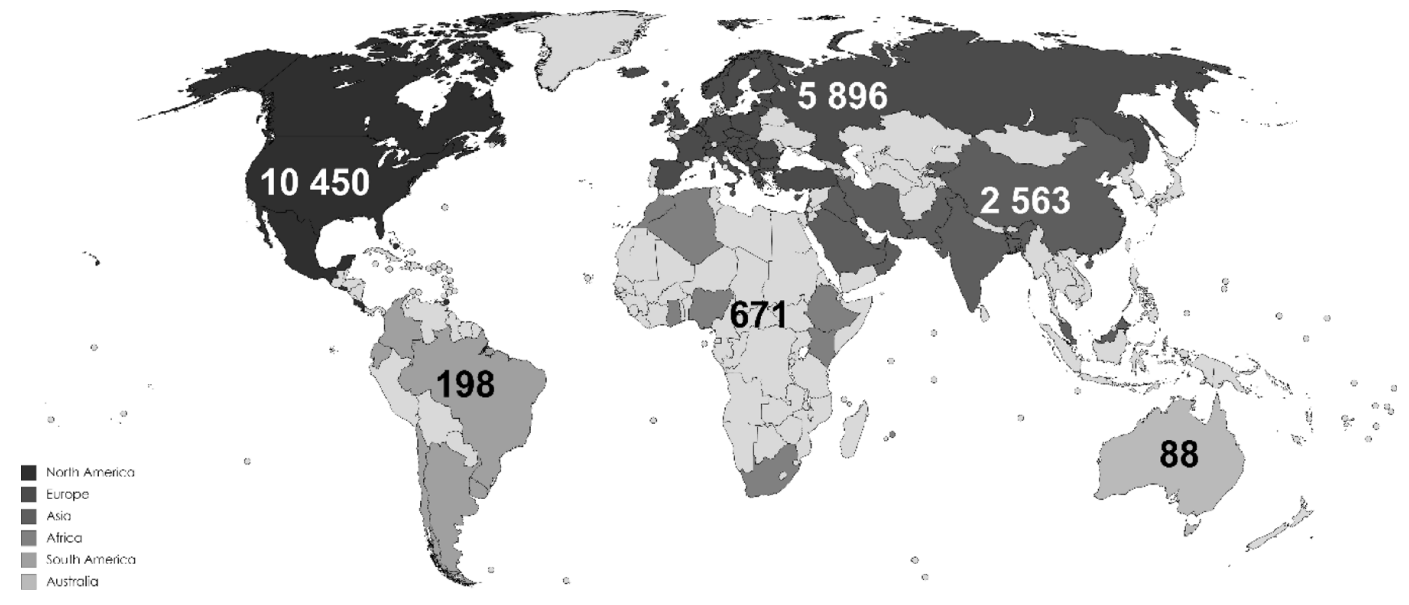

Table 1. Respondents' profile

\begin{tabular}{|c|c|c|c|c|c|c|}
\hline \multirow{2}{*}{$\begin{array}{l}\text { Respondent's } \\
\text { Information }\end{array}$} & \multicolumn{2}{|c|}{ Total } & \multicolumn{2}{|c|}{ Male } & \multicolumn{2}{|c|}{ Female } \\
\hline & Number & Percent & Number & Percent & Number & Percent \\
\hline \multicolumn{7}{|c|}{ Age } \\
\hline Below 25 & 561 & $2.81 \%$ & 209 & $1.05 \%$ & 352 & $1.76 \%$ \\
\hline $25-34$ & 3465 & $17.34 \%$ & 1518 & $7.59 \%$ & 1947 & $9.75 \%$ \\
\hline $35-44$ & 4950 & $24.76 \%$ & 2453 & $12.27 \%$ & 2497 & $12.49 \%$ \\
\hline $45-54$ & 5346 & $26.75 \%$ & 2475 & $12.39 \%$ & 2871 & $14.36 \%$ \\
\hline Above 55 & 5665 & $28.34 \%$ & 3289 & $16.45 \%$ & 2376 & $11.89 \%$ \\
\hline \multicolumn{7}{|c|}{ Degree } \\
\hline $\mathrm{PhD}$ & 10010 & $50.08 \%$ & 6017 & $30.10 \%$ & 3993 & $19.98 \%$ \\
\hline D.Sc. & 693 & $3.47 \%$ & 396 & $1.98 \%$ & 297 & $1.49 \%$ \\
\hline Other & 9284 & $46.45 \%$ & 3531 & $17.67 \%$ & 5753 & $18.78 \%$ \\
\hline \multicolumn{7}{|c|}{ Faculty Position } \\
\hline Assistant & 1210 & $6.05 \%$ & 583 & $2.92 \%$ & 627 & $3.13 \%$ \\
\hline Assistant Professor & 4829 & $24.16 \%$ & 2618 & $13.10 \%$ & 2211 & $11.06 \%$ \\
\hline Associate Professor & 3487 & $17.45 \%$ & 1969 & $9.86 \%$ & 1518 & $7.59 \%$ \\
\hline Professor & 4697 & $23.50 \%$ & 2585 & $12.93 \%$ & 2112 & $10.57 \%$ \\
\hline Other & 5764 & $28.84 \%$ & 2189 & $10.95 \%$ & 3575 & $17.89 \%$ \\
\hline
\end{tabular}

Bebo, Myspace, LinkedIn, etc.)?". Figure 2 presents the percentage of answers given by teachers according to their faculty position and age group.

\section{Survey Results}

An analysis of the answers given to the statements from Section 2 shows that a significant smaller part of surveyed teachers use social networking sites to communicate with their students $(51.96 \%$ 


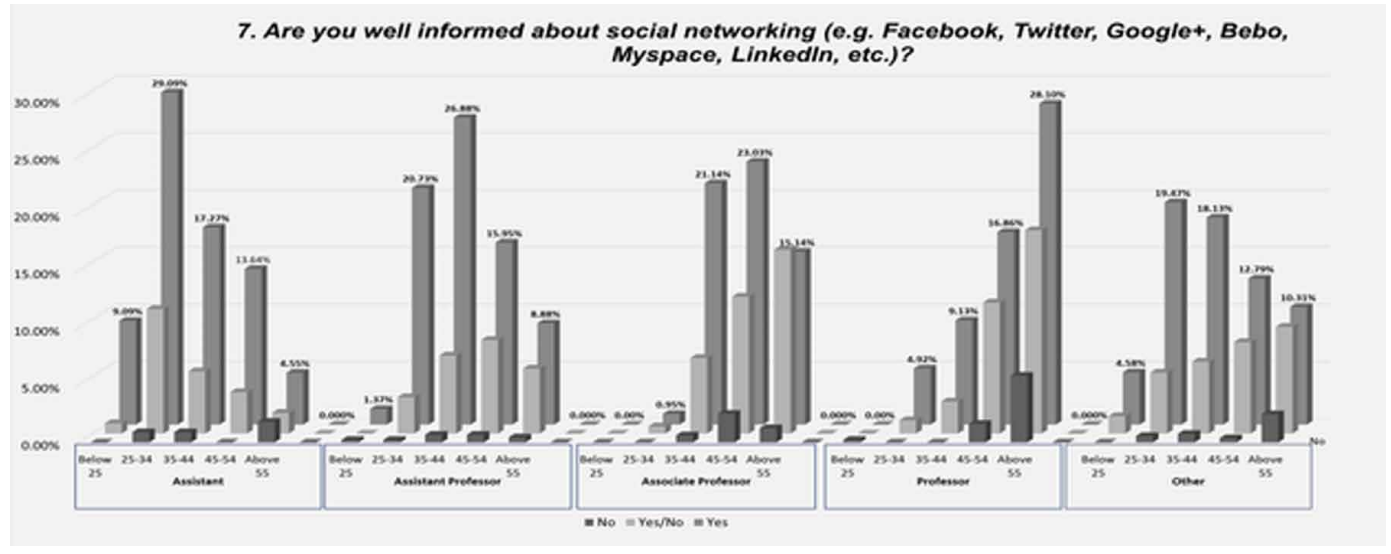

answered SD or D, and $18.27 \%$ answered $\mathrm{N}$ to Statement 8 ) and participate in online social networking groups for information sharing, discussion and organization of courses $(56.80 \%$ answered SD or D to Statement 9, and $60.54 \%$ answered SD or D to Statement 10). The percentage of teachers who believe that the use of social networking during lessons increases the engagement of students is even smaller - only $18.40 \%$ (see answers to Statement 11 ). The number of teachers who participate in online groups interested in the use of social networking for educational purposes is also small - $32.63 \%$. $53.03 \%$ of the surveyed teachers have a public profile in a social networking site to share research interests and to connect with like-minded people (Statement 13). Finally, when teachers are asked to agree that the use of social networking has a positive effect on student achievement and increases the involvement and interest of students in their course, 39.62\% of teachers stated that they are SD or D with Statement 14 and $41.06 \%$ of teachers stated that they are SD or D with Statement 15 . Table 2 presents summarized results of Section 2.

According to the answers given on the open-ended question in Section 2 only about $30 \%$ of the surveyed teachers actually use social networking for the following purposes:

- communication and consultations;

- holding discussions on the courses, highlighting of some topics, sharing of lecture notes;

- increasing students' involvement, cooperation and interest;

- encouraging creative writing;

- $\quad$ sending additional material and sharing information;

- guiding students through assignments/projects and managing progress on projects;

- organising learning activities on specific courses or as a whole and keeping students up-to-date on class activities, homework, assignments, midterms;

- $\quad$ sharing research, best practises and communication with colleagues;

- publishing events, activities and stories of interest to students;

- announcing and sending invites to workshops, conferences and other professional events;

- course promotion;

- contacting alumni and former students;

- $\quad$ starting discussions and exchange of ideas/opinions;

- $\quad$ building networks between students from different programs or years;

- helping students connect to professionals in their field of interest. 
Table 2. Use of social networking sites in teaching practice

\begin{tabular}{|c|c|c|c|c|c|}
\hline Statement & $1=\mathrm{SD}$ & $2=D$ & $3=N$ & $4=A$ & $5=S A$ \\
\hline $\begin{array}{l}\text { 8. You often use social networking sites for } \\
\text { communication and consultation with your students. }\end{array}$ & $\begin{array}{c}6919 \\
(34.62 \%)\end{array}$ & $\begin{array}{c}3465 \\
(17.34 \%)\end{array}$ & $\begin{array}{c}3652 \\
(18.27 \%)\end{array}$ & $\begin{array}{c}3608 \\
(18.05 \%)\end{array}$ & $\begin{array}{c}2343 \\
(11.72 \%)\end{array}$ \\
\hline $\begin{array}{l}\text { 9. You participate in social networking group/groups } \\
\text { with your students for information sharing and } \\
\text { discussions on the courses. }\end{array}$ & $\begin{array}{c}7777 \\
(38.91 \%)\end{array}$ & $\begin{array}{c}3575 \\
(17.89 \%)\end{array}$ & $\begin{array}{c}3454 \\
(17.28 \%)\end{array}$ & $\begin{array}{c}3256 \\
(16.29 \%)\end{array}$ & $\begin{array}{c}1925 \\
(9.63 \%)\end{array}$ \\
\hline $\begin{array}{l}\text { 10. You participate in social networking group/ } \\
\text { groups with your students for organization of the } \\
\text { courses. }\end{array}$ & $\begin{array}{c}7777 \\
(42.38 \%)\end{array}$ & $\begin{array}{c}3630 \\
(18.16 \%)\end{array}$ & $\begin{array}{c}3300 \\
(16.51 \%)\end{array}$ & $\begin{array}{c}2948 \\
(14.75 \%)\end{array}$ & $\begin{array}{c}1639 \\
(8.20 \%)\end{array}$ \\
\hline $\begin{array}{l}\text { 11. You use social networking sites during lessons } \\
\text { in order to increase students' involvement and to } \\
\text { keep track of their reactions. }\end{array}$ & $\begin{array}{c}9526 \\
(47.84 \%)\end{array}$ & $\begin{array}{c}4004 \\
(20.11 \%)\end{array}$ & $\begin{array}{c}2717 \\
(13.65 \%)\end{array}$ & $\begin{array}{c}2299 \\
(11.55 \%)\end{array}$ & $\begin{array}{c}1364 \\
(6.85 \%)\end{array}$ \\
\hline $\begin{array}{l}\text { 12. You participate in online group/groups } \\
\text { interested in the use of social networking for } \\
\text { educational purposes. }\end{array}$ & $\begin{array}{c}6963 \\
(34.84 \%)\end{array}$ & $\begin{array}{c}3091 \\
(15.47 \%)\end{array}$ & $\begin{array}{c}3410 \\
(17.06 \%)\end{array}$ & $\begin{array}{c}4092 \\
(20.47 \%)\end{array}$ & $\begin{array}{c}2431 \\
(12.16 \%)\end{array}$ \\
\hline $\begin{array}{l}\text { 13. You have a public profile in some social } \\
\text { networking sites to share your research interests and } \\
\text { to connect with a wide range of people with similar } \\
\text { preferences. }\end{array}$ & $\begin{array}{c}3630 \\
(18.17 \%)\end{array}$ & $\begin{array}{c}2365 \\
(11.84 \%)\end{array}$ & $\begin{array}{c}3338 \\
(16.96 \%)\end{array}$ & $\begin{array}{c}5346 \\
(26.76 \%)\end{array}$ & $\begin{array}{c}5247 \\
(26.27 \%)\end{array}$ \\
\hline $\begin{array}{l}\text { 14. The use of social networking sites in your } \\
\text { teaching practice has a positive effect on student } \\
\text { achievements. }\end{array}$ & $\begin{array}{c}5489 \\
(27.46 \%)\end{array}$ & $\begin{array}{c}2431 \\
(12.16 \%)\end{array}$ & $\begin{array}{c}6424 \\
(32.14 \%)\end{array}$ & $\begin{array}{c}3630 \\
(18.33 \%)\end{array}$ & $\begin{array}{c}1980 \\
(9.91 \%)\end{array}$ \\
\hline $\begin{array}{l}\text { 15. The use of social networking sites in your } \\
\text { teaching practice increases the involvement and } \\
\text { interest of students in the training. }\end{array}$ & $\begin{array}{c}5676 \\
(28.40 \%)\end{array}$ & $\begin{array}{c}2530 \\
(12.66 \%)\end{array}$ & $\begin{array}{c}5720 \\
(28.62 \%)\end{array}$ & $\begin{array}{c}4048 \\
(20.25 \%)\end{array}$ & $\begin{array}{c}2013 \\
(10.07 \%)\end{array}$ \\
\hline
\end{tabular}

The majority of teachers (see. Table 3.) agree that the use of social networking in education can be useful - 24.71\% answered SA to Statement 17 and $36.05 \%$ answered A. Significantly greater is the number of teachers who agree that the role of social networking in education will increase $-36.12 \%$ answered SA and $37.83 \%$ answered A to Statement 18. This shows that despite the relatively low rate of the current use of social networking, the majority of teachers tend to use social networks in the future. The answers given to Statement 19 show that the low rate of use of social networks at the moment is probably due also to the low level of participation of teachers in research on the use of social networking in education - only 5764 teachers (28.97\%) stated participation in such research.

The answers to the open-ended question at the end of Section 3 gave more insights into why teachers today have a negative attitude towards the use of social networking for organizational/teaching activities for the following reasons:

- distraction of the students and incompatibility with data protection regulations;

- lack of person-to-person natural and intuitive communication and valuable direct interaction;

- social networking sites are too informal and give students too much freedom;

- it requires time to manage it - from setting up a social network channel for a course, to updating the social media channel, to monitoring and commenting on it;

- it is hard to stay current with all the different social networking apps that students use;

- danger of superficiality, lack of a reflective approach to learning;

- sharing mechanisms blur the boundary between private and public/academic audience;

- it is not a reflexive research-tool and does not allow for thorough ethical review process; 
Table 3. Use of social networking for educational purposes in general

\begin{tabular}{|l|c|c|c|c|c|}
\hline \multicolumn{1}{|c|}{ Statement } & 1=SD & 2=D & 3=N & 4=A & 5=SA \\
\hline $\begin{array}{l}\text { 17. Social networking sites are/can be useful in } \\
\text { education. }\end{array}$ & $\begin{array}{c}1210 \\
(6.05 \%)\end{array}$ & $\begin{array}{c}1749 \\
(8.75 \%)\end{array}$ & $\begin{array}{c}4884 \\
(24.44 \%)\end{array}$ & $\begin{array}{c}7205 \\
(36.05 \%)\end{array}$ & $\begin{array}{c}4939 \\
(24.71 \%)\end{array}$ \\
\hline 18. The role of social networking sites will increase. & $\begin{array}{c}902 \\
(4.52 \%)\end{array}$ & $\begin{array}{c}1001 \\
(5.01 \%)\end{array}$ & $\begin{array}{c}3300 \\
(16.52 \%)\end{array}$ & $\begin{array}{c}7557 \\
(37.83 \%)\end{array}$ & $\begin{array}{c}7216 \\
(36.12 \%)\end{array}$ \\
\hline $\begin{array}{l}\text { 19. You participate in research related to the use of } \\
\text { social networking sites in education. }\end{array}$ & $\begin{array}{c}7150 \\
(35.93 \%)\end{array}$ & $\begin{array}{c}3366 \\
(16.91 \%)\end{array}$ & $\begin{array}{c}3619 \\
(18.19 \%)\end{array}$ & $\begin{array}{c}3399 \\
(17.08 \%)\end{array}$ & $\begin{array}{c}2365 \\
(11.89 \%)\end{array}$ \\
\hline
\end{tabular}

- $\quad$ plagiarism, lack of motivation, laziness of thought and analytical skills, severe drop in communication and presentation skills, etc.;

- $\quad$ some issues connected to privacy, security, archiving, and ethics;

- in terms of knowledge sharing, it dilutes the information and the objective value is subjected to crowd (mis)interpretation;

- it can blur boundaries between students and instructors;

- it is likely that social media will devalue the role of academics and education;

- too many boundaries and ethical issues that higher education has yet to address.

Overall, the survey results show that teachers have a negative attitude towards the use of social networking in their teaching practice (an average score 2.58 on the eight statements from Section 2 of the questionnaire). Although the surveyed teachers do not use social networking sites in their teaching practice now, they believe that social networking sites can be useful for education in general and have a positive attitude towards the use of social networking for educational purposes (an average score 3.38 on the three statements from Section 3 of the questionnaire). Figure 3 presents the average scores on statements from Section 2 and Section 3 of the questionnaire given by the teachers.

The survey results do not confirm results of the same survey conducted in Bulgaria (Doneva \& Gaftandzhieva, 2017). Unlike their colleagues around the world, teachers in Bulgaria more actively use social networking sites for communication with their students. Part of the Bulgarian teachers use social networking sites for information sharing, discussions and course organization. Surveyed teachers within this survey are more active than Bulgarian teachers in the use of social networking during lesson and participate in online groups interested in the use of social networking for educational purposes. Bulgarian teachers gave significantly higher scores on statements that the role of social networking in education will increase and social networking can be useful for education, but they are less involved in research related to the use of social networking in education than their colleagues from other countries.

Most results are in line with the findings of other surveys on the use of social networking in education. For example, some surveys conducted among teachers (Hendee, 2014; Faculty Focus, 2011) show that teachers do not use social networks for communication with their students and prefer to use conventional communication channels (email, phone calls, and text messaging respectively). The conclusion that a small number of teachers uses social networking during lessons also confirms the results of another survey (Hendee, 2014). The finding that most teachers use social networking sites to share their research interests and to connect with a wide range of people with similar preferences, confirms the results of the survey conducted by MMS Education (edWeb, 2009). This survey concludes that teachers use social networking to share information and resources with educators, to create professional learning communities and to connect with peers and colleagues. Moreover, the positive attitude of the teachers towards the statements that social networking sites can be useful in education and their role in education will increase, substantiates the teachers' expectation to increase their use of social media in the future (Faculty Focus, 2011). The finding that most teachers use social 


\section{Average Scores}

\section{5}

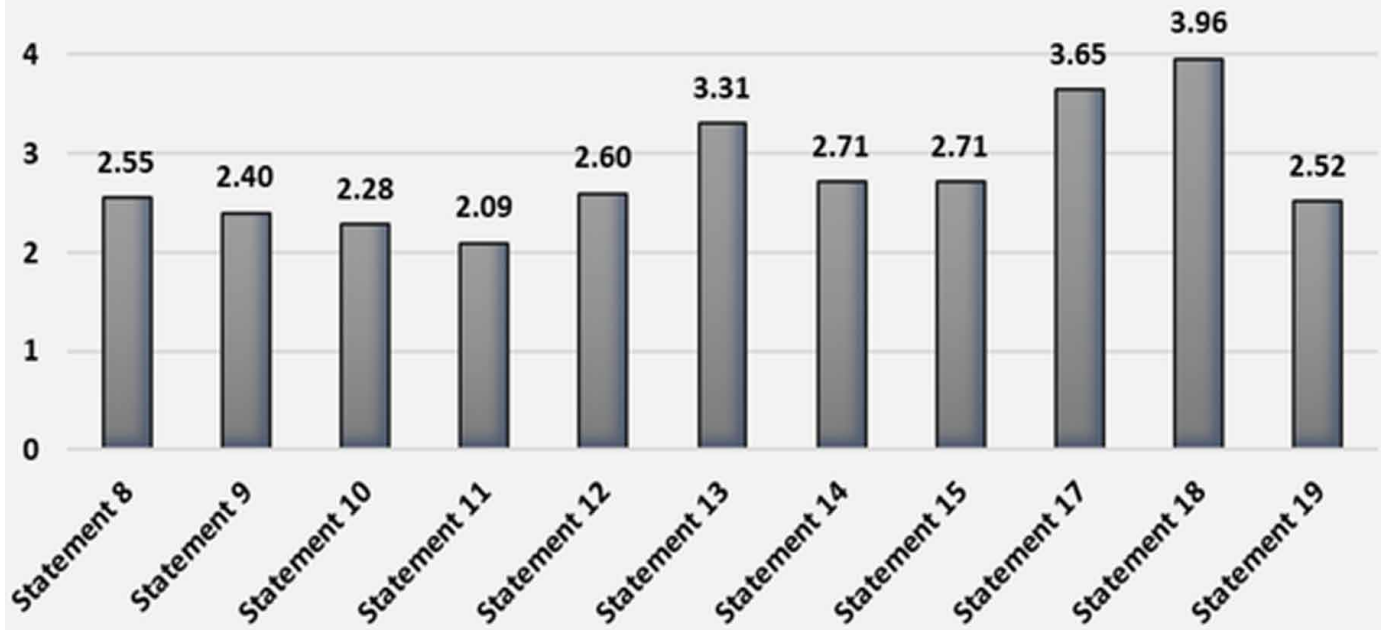

networking sites to share their research interests and to connect with a wide range of people with similar preferences confirms the results of other surveys (edWeb, 2009). However, some of the findings from the current survey do not correspond to those of other studies. This study's conclusions that the use of social networks doesn't increase students' engagement and interest while studying their course differ from the conclusions of other studies, according to which the use of social networks improve students' engagement in their course and their educational experience, on the one hand (Hendee, 2014; Mardikyan \& Bozanta, 2017; Rutherford, 2010; Rodriguez, 2011; Junco, Elavsky, \& Heiberger, 2013) and peer interaction and students' interaction with faculty members, on the other (Zanamwe, Rupere, \& Kufandirimbwa, 2013; Mardikyan \& Bozanta, 2017). The finding does not corroborate the results of another study (Kolan \& Dzandza, 2018), according to which the use of social networking increases their understanding of topics discussed in class and improves their grades. This persuasion contradicts the opinion of surveyed teachers that the use of social networking sites in their teaching practice does not have a positive effect on student achievements.

\section{Analysis According To The Teachers' Level of Information About Social Networking (Answer To Research Question RQ1)}

The analysis of the answers to Question 7 shows that not all of the surveyed teachers are well informed about the social networking. Therefore, it is natural teachers who are not familiar with social networking to use them less often in their teaching practice and not to be positive about their use in education. A detailed analysis of the answers to all questions was made to examine the extent to which the use of social networking in the academic practice of the surveyed teachers and their opinion on the use of social networking for education purposes in general are related to the teachers' extent of knowledge about social networking.

Figure 4 and Figure 5 present detailed results in percentage of the answers to the statements from Section 2 and Section 3 of the questionnaire, which teachers gave according to their level of information about social networking. The analysis shows that the most positive attitude towards the use of social networks in teaching practice and in education pertains to teachers (answered SA and A 
Figure 4. Percentage of answers to Question 8-15 according to degree of information about social networking

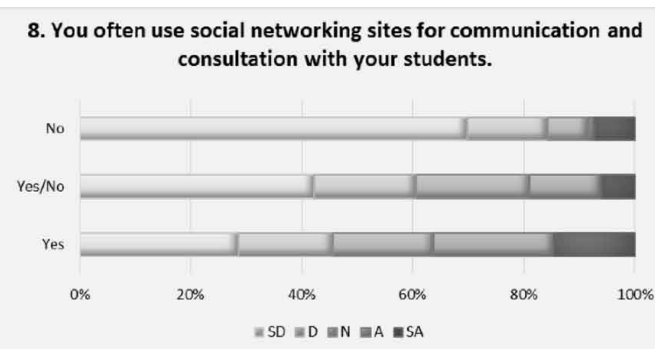

10. You participate in social networking group/groups with your students for organization of the learning courses.

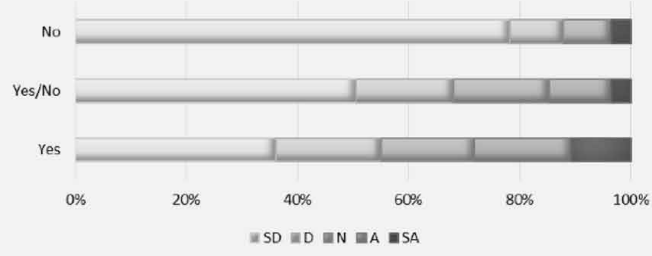

12. You participate in online group/groups interesting in the use of social networking for educational purposes.

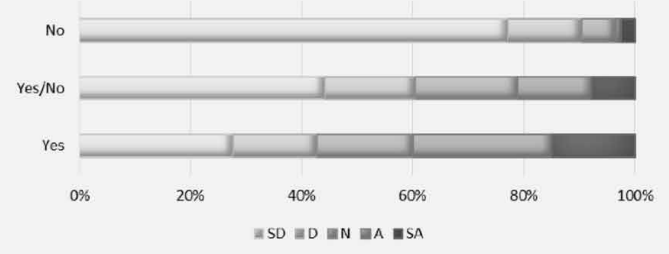

14. The use of social networking sites in your teaching practice has a positive effect on the student achievements.

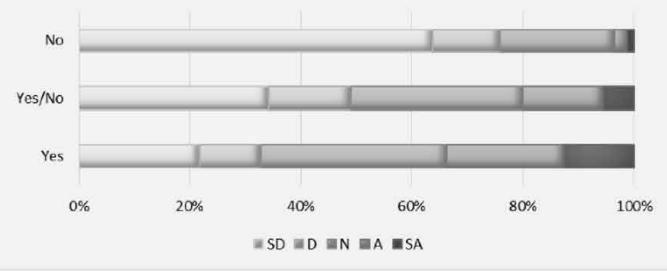

9. You participate in social networking group/groups with your students for information sharing and discussions on the learning courses.

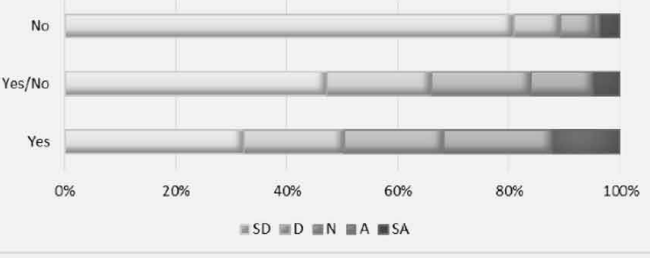

11. You use social networking sites during the lesson in order to increase students' involvement and to keep track of their reactions.

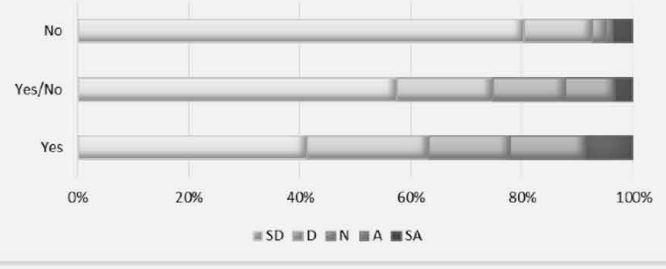

13. You have a public profile in some of social networking sites to share yours research interests and to connect with a wide range of people with similar preferences.

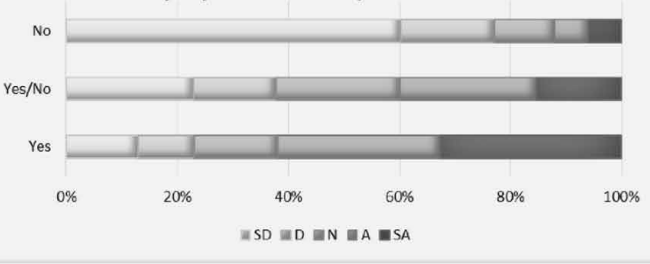

15. The use of social networking sites in your teaching practice increases the involvement and interest of students in the training.

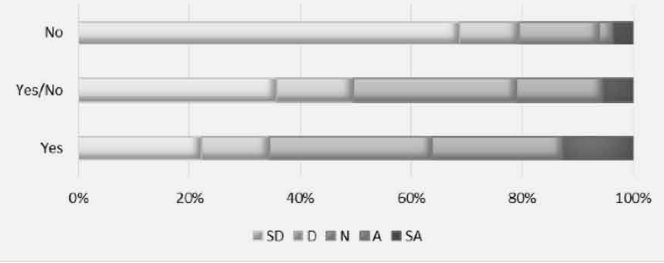

to the statements from Section 2 and Section 3) who are familiar with social networking (answered Yes to Question 7), followed by teachers who are not fully informed about social networking (answered Yes/No to Question 7). It is interesting to note that even teachers who answered they are unfamiliar with social networking believe that social networking sites can be useful for education and they are convinced that the role of social networks in education will increase (see Figure 5).

The analysis shows that teachers who are familiar with social networking gave the highest average scores (first column), followed by teachers who are not fully informed about social networking (second column) and teachers who are not familiar with social networks at all (third column). Overall, teachers from all groups do not use social networking in their teaching practice and gave an average score below 3 to the statements in Section 2. Although teachers do not use social networking sites now and they do not participate actively in research related to the use of social networking sites in education (an average score below 3 to Statement 19 by all groups of the surveyed teachers), all teachers are positive about the use of social networking in education, believe that social networking sites can be 
Figure 5. Percentage of answers to Questions 17-19 according to degree of information about social networking

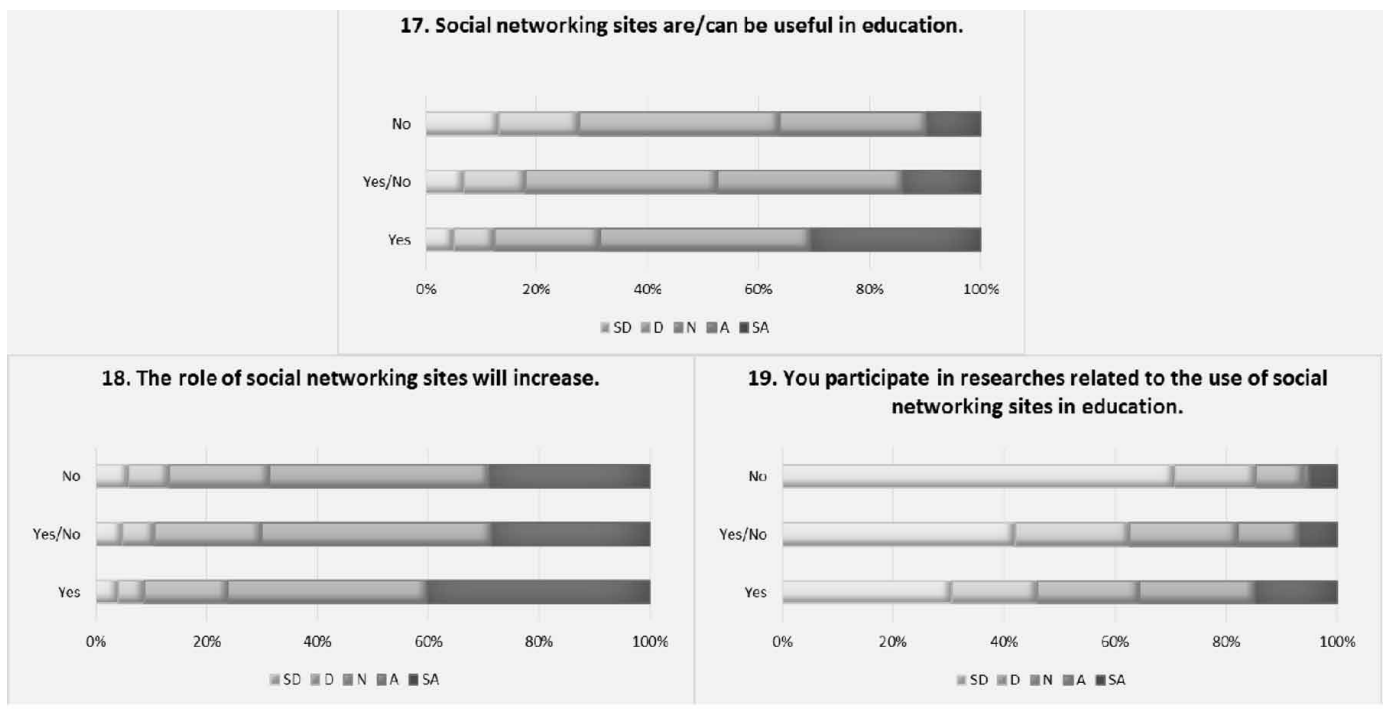

useful for education and they are convinced that their role in education will increase (an average score above 3 to Statement 17 and to Statement 18 by all groups of the surveyed teachers).

\section{Analysis According To The Teachers' Participation in Groups (Answer To Research Question RQ2)}

A small part of the surveyed teachers participate in groups interested in the use of social networking for educational purposes - only 6523 (32.64\%) of the surveyed teachers answered A or SA to Statement 12. You participate in online group/groups interested in the use of social networking for educational purposes. Significantly higher is the number of teachers who do not participate in groups interested

Figure 6. Average scores on statements from Section 2 and Section 3 according to degree of information about social networking

\section{Average Scores}

5

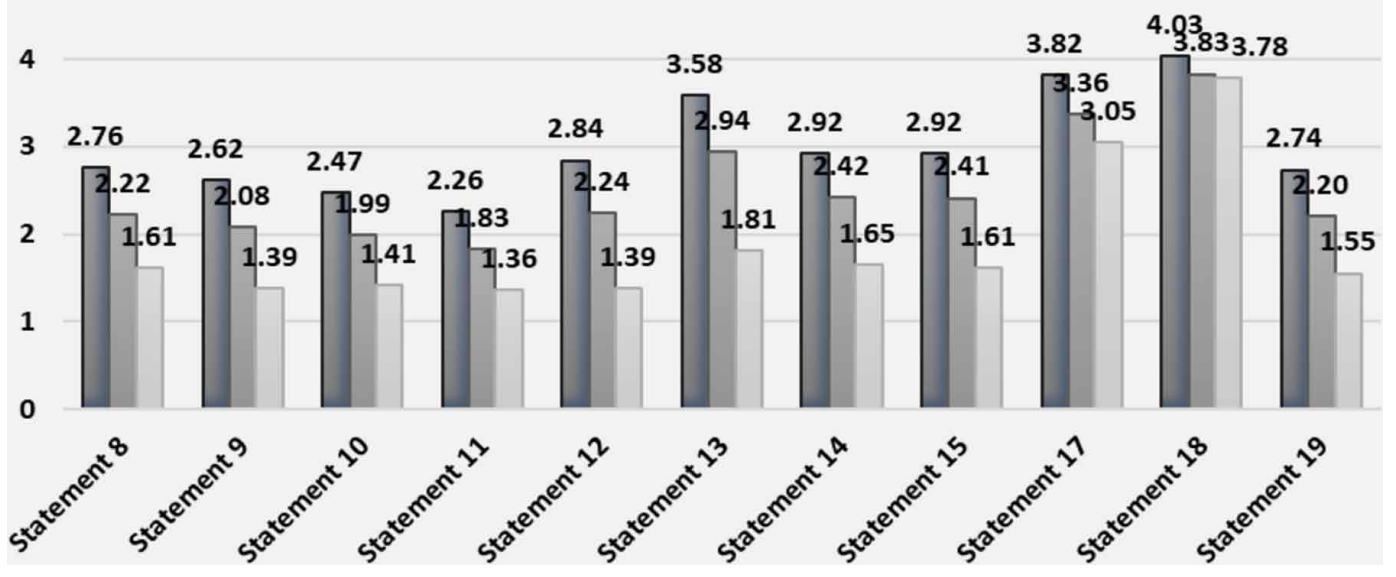


in the use social networks for educational purposes - 10054 of the surveyed teachers answered SD or D to Statement $12(50.31 \%)$.

Table 4 presents the number of answers given by the teachers who do not participate in groups interested in the use of social networking for educational purposes. The results show that teachers who do not participate in such groups rarely use social networking sites in their teaching practice. The analysis of answers shows that teachers are skeptical towards the use of social networking for communication and consultation with their students, discussions on the studied material and organization of training courses - only $12.03 \%$ answered A or SA to Statement 8, 9.73\% answered A or SA to Statement 9 and $6.23 \%$ answered A or SA to Statement 10. Most teachers are strongly against the use of social networking sites during lessons - only $4.06 \%$ of teachers gave answers A or SA to Statement 11. Teachers are skeptical that the use of social networking sites has a positive effect on students' achievements and that it increases their involvement and interest in the training $-9.20 \%$ of teachers gave answer A or SA to Statement 14 and $10.07 \%$ of teachers gave answer A or SA to Statement 15.

The teachers who participate in groups interested in the use of social networking for educational purposes are more positive and actively use social networks in their teaching practice. Table 5 presents the number of responses from teachers participating in such groups. The analysis of answers shows that most of the surveyed teachers use social networking for communication and consultation with their students, discussions on the studied material and organization of courses $-56.16 \%$ answered SA or A to Statement 8, 52.28\% answered A or SA to Statement 9 and $49.92 \%$ answered A or SA to Statement 10. A significant part of surveyed teachers have a positive attitude towards the use of social networking sites during lessons $-42.37 \%$ of teachers answered A or SA to Statement 11 . Most teachers believe that the use of social networking sites has a positive effect on students' achievements

Table 4. Use of social networking sites in teaching practice according to answers on Statement 12 (SD=1 and $D=2)$

\begin{tabular}{|c|c|c|c|c|c|}
\hline Statement & $\mathrm{SD}=1$ & $D=2$ & $\mathbf{N}=3$ & $A=4$ & $\mathrm{SA}=5$ \\
\hline $\begin{array}{l}\text { 8. You often use social networking sites for } \\
\text { communication and consultation with your } \\
\text { students. }\end{array}$ & $\begin{array}{c}5511 \\
(54.81 \%)\end{array}$ & $\begin{array}{c}2134 \\
(21.23 \%)\end{array}$ & $\begin{array}{c}1199 \\
(11.93 \%)\end{array}$ & $\begin{array}{c}671 \\
(6.67 \%)\end{array}$ & $\begin{array}{c}539 \\
(5.36 \%)\end{array}$ \\
\hline $\begin{array}{l}\text { 9. You participate in social networking group/ } \\
\text { groups with your students for information } \\
\text { sharing and discussions on the courses. }\end{array}$ & $\begin{array}{c}6248 \\
(62.15 \%)\end{array}$ & $\begin{array}{c}2035 \\
(20.24 \%)\end{array}$ & $\begin{array}{c}792 \\
(7.88 \%)\end{array}$ & $\begin{array}{c}671 \\
(6.67 \%)\end{array}$ & $\begin{array}{c}539 \\
(3.06 \%)\end{array}$ \\
\hline $\begin{array}{l}\text { 10. You participate in social networking group/ } \\
\text { groups with your students for organization of } \\
\text { the courses. }\end{array}$ & $\begin{array}{c}6765 \\
(67.29 \%)\end{array}$ & $\begin{array}{c}1848 \\
(18.38 \%)\end{array}$ & $\begin{array}{c}814 \\
(8.10 \%)\end{array}$ & $\begin{array}{c}451 \\
(4.48 \%)\end{array}$ & $\begin{array}{c}176 \\
(1.75 \%)\end{array}$ \\
\hline $\begin{array}{l}\text { 11. You use social networking sites during } \\
\text { lessons in order to increase students' } \\
\text { involvement and to keep track of their reactions. }\end{array}$ & $\begin{array}{c}7271 \\
(72.56 \%)\end{array}$ & $\begin{array}{c}1958 \\
(19.54 \%)\end{array}$ & $\begin{array}{c}385 \\
(3.84 \%)\end{array}$ & $\begin{array}{c}286 \\
(2.85 \%)\end{array}$ & $\begin{array}{c}121 \\
(1.21 \%)\end{array}$ \\
\hline $\begin{array}{l}\text { 13. You have a public profile in some social } \\
\text { networking sites to share your research interests } \\
\text { and to connect with a wide range of people with } \\
\text { similar preferences. }\end{array}$ & $\begin{array}{c}3146 \\
(31.29 \%)\end{array}$ & $\begin{array}{c}1518 \\
(15.10 \%)\end{array}$ & $\begin{array}{c}1485 \\
(14.77 \%)\end{array}$ & $\begin{array}{c}2145 \\
(21.33 \%)\end{array}$ & $\begin{array}{c}1760 \\
(17.51 \%)\end{array}$ \\
\hline $\begin{array}{l}\text { 14. The use of social networking sites in your } \\
\text { teaching practice has a positive effect on student } \\
\text { achievements. }\end{array}$ & $\begin{array}{c}4796 \\
(47.71 \%)\end{array}$ & $\begin{array}{c}1496 \\
(14.86 \%)\end{array}$ & $\begin{array}{c}2838 \\
(28.23 \%)\end{array}$ & $\begin{array}{c}627 \\
(6.24 \%)\end{array}$ & $\begin{array}{c}297 \\
(2.96 \%)\end{array}$ \\
\hline $\begin{array}{l}\text { 15. The use of social networking sites in your } \\
\text { teaching practice increases the involvement and } \\
\text { interest of students in the training. }\end{array}$ & $\begin{array}{c}4807 \\
(47.81 \%)\end{array}$ & $\begin{array}{c}1672 \\
(16.63 \%)\end{array}$ & $\begin{array}{c}2563 \\
(25.49 \%)\end{array}$ & $\begin{array}{c}693 \\
(6.89 \%)\end{array}$ & $\begin{array}{c}319 \\
(3.18 \%)\end{array}$ \\
\hline
\end{tabular}


Table 5. Use of social networking sites in teaching practice according to answers on Statement $12(A=4$ and $S A=5)$

\begin{tabular}{|c|c|c|c|c|c|}
\hline Statement & $\mathrm{SD}=1$ & $D=2$ & $\mathbf{N}=\mathbf{3}$ & $A=4$ & $\mathbf{S A}=5$ \\
\hline $\begin{array}{l}\text { 8. You often use social networking sites for } \\
\text { communication and consultation with your } \\
\text { students. }\end{array}$ & $\begin{array}{c}770 \\
(11.80 \%)\end{array}$ & $\begin{array}{c}781 \\
(11.97 \%)\end{array}$ & $\begin{array}{c}1309 \\
(20.07 \%)\end{array}$ & $\begin{array}{c}2178 \\
(33.39 \%)\end{array}$ & $\begin{array}{c}1485 \\
(22.77 \%)\end{array}$ \\
\hline $\begin{array}{l}\text { 9. You participate in social networking group/ } \\
\text { groups with your students for information sharing } \\
\text { and discussions on the courses. }\end{array}$ & $\begin{array}{c}836 \\
(12.82 \%)\end{array}$ & $\begin{array}{c}946 \\
(14.50 \%)\end{array}$ & $\begin{array}{c}1331 \\
(20.40 \%)\end{array}$ & $\begin{array}{c}2024 \\
(31.03 \%)\end{array}$ & $\begin{array}{c}1386 \\
(21.25 \%)\end{array}$ \\
\hline $\begin{array}{l}\text { 10. You participate in social networking group/ } \\
\text { groups with your students for organization of the } \\
\text { courses. }\end{array}$ & $\begin{array}{c}946 \\
(14.50 \%)\end{array}$ & $\begin{array}{c}1089 \\
(16.69 \%)\end{array}$ & $\begin{array}{c}1232 \\
(18.89 \%)\end{array}$ & $\begin{array}{c}1958 \\
(30.02 \%)\end{array}$ & $\begin{array}{c}1298 \\
(19.90 \%)\end{array}$ \\
\hline $\begin{array}{l}\text { 11. You use social networking sites during } \\
\text { lessons in order to increase students' involvement } \\
\text { and to keep track of their reactions. }\end{array}$ & $\begin{array}{c}1375 \\
(21.19 \%)\end{array}$ & $\begin{array}{c}1221 \\
(18.81 \%)\end{array}$ & $\begin{array}{c}1144 \\
(17.63 \%)\end{array}$ & $\begin{array}{c}1650 \\
(25.42 \%)\end{array}$ & $\begin{array}{c}1100 \\
(16.95 \%)\end{array}$ \\
\hline $\begin{array}{l}\text { 13. You have a public profile in some social } \\
\text { networking sites to share your research interests } \\
\text { and to connect with a wide range of people with } \\
\text { similar preferences. }\end{array}$ & $\begin{array}{c}253 \\
(3.88 \%)\end{array}$ & $\begin{array}{c}396 \\
(6.08 \%)\end{array}$ & $\begin{array}{c}836 \\
(12.84 \%)\end{array}$ & $\begin{array}{c}2244 \\
(34.46 \%)\end{array}$ & $\begin{array}{c}2783 \\
(42.74 \%)\end{array}$ \\
\hline $\begin{array}{l}\text { 14. The use of social networking sites in your } \\
\text { teaching practice has a positive effect on student } \\
\text { achievements. }\end{array}$ & $\begin{array}{c}286 \\
(4.38 \%)\end{array}$ & $\begin{array}{c}484 \\
(7.42 \%)\end{array}$ & $\begin{array}{c}1947 \\
(29.85 \%)\end{array}$ & $\begin{array}{c}2343 \\
(35.92 \%)\end{array}$ & $\begin{array}{c}1463 \\
(22.43 \%)\end{array}$ \\
\hline $\begin{array}{l}\text { 15. The use of social networking sites in your } \\
\text { teaching practice increases the involvement and } \\
\text { interest of students in the training. }\end{array}$ & $\begin{array}{c}363 \\
(5.56 \%)\end{array}$ & $\begin{array}{c}484 \\
(7.42 \%)\end{array}$ & $\begin{array}{c}1639 \\
(25.13 \%)\end{array}$ & $\begin{array}{c}2629 \\
(40.30 \%)\end{array}$ & $\begin{array}{c}1408 \\
(21.59 \%)\end{array}$ \\
\hline
\end{tabular}

and that it increases their involvement and interest in the training $-58.35 \%$ of teachers answered A or SA to Statement 14 and $61.89 \%$ of teachers answered A or SA to Statement 15.

The analysis of the answers clearly shows (see Figure 7) that teachers who participate in groups interested in the use of social networking sites for educational purposes gave higher average scores on all statements in Section 2. These teachers gave an average score above 3 to six statements in Section 2. Although they have a positive attitude towards social networking in general, a significant small part of them use social networking sites during lessons - an average score 2.98 on Statement 11.

\section{Analysis According To The Teachers' Participation In Research For Social Networking (Answer To Research Question RQ3)}

Analysis of the answers to Statement 19. You participate in research related to the use of social networking sites in education shows that a significant small part of the teachers participate in research related to the use of social networking sites in education - only 5764 (28.97\%) of the surveyed teachers answered A or SA. More than half of the surveyed teachers do not participate in such research -10 516 of the teachers answered SD or D to Statement 19 (52.84\%) (see Table 3, Statement 19). In order to establish the extent to which the positive attitude towards the use of social networking in education of the surveyed teachers is related to their scientific interests, a detailed analysis of the answers to all statements in Section 3 according to the teachers' participation in social networking research was made.

Table 6 and Table 7 present the analysis of the answers to the statements in Section 3 of the questionnaire according to teachers' participation in research related to the use of social networking sites in education. The analysis of the answers shows that teachers who do not participate in research related to the use of social networking believe that the use of social networking in education can have a positive effect and their role in education will increase $-47.80 \%$ answered A or SA to Statement 17 and $66.49 \%$ answered A or SA to Statement 18 (see Table 6). Most of the surveyed teachers that 
Figure 7. Average scores on statements from Section 2 according to answers on Statement 12

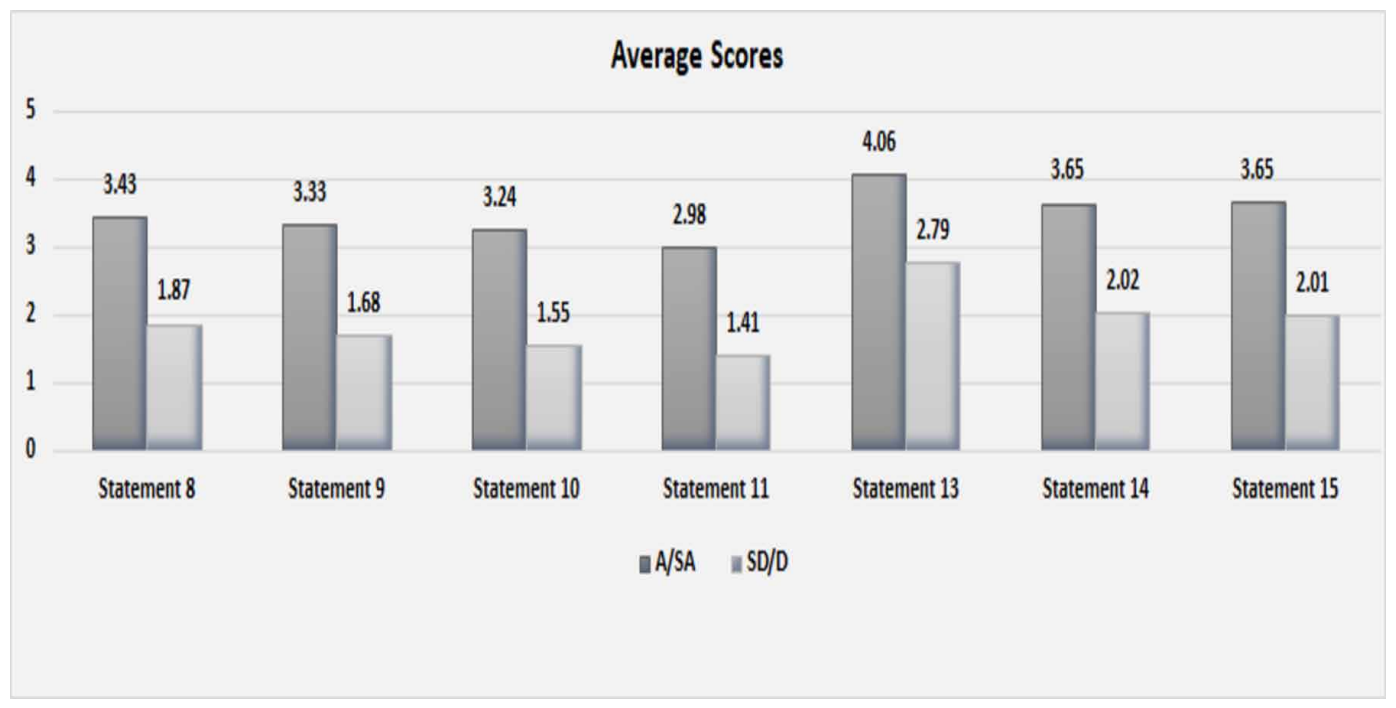

participate in such research have a positive attitude towards the use of social networking sites for educational purposes in general - only $330(5.73 \%)$ teachers stated that social networking sites can't be useful in education and $242(4.20 \%)$ teachers stated that their role will not increase (see Table 7).

The analysis of the answers clearly shows (see Figure 8) that all teachers gave high average scores (above 3) to Statement 17 and Statement 18. Logically teachers who participate in research related to the use of social networking sites in education are more positive to their use and gave higher average scores (above 4).

Table 6. Use of social networking for educational purposes in general according to answers on Statement $19(S D=1$ and $D=2)$

\begin{tabular}{|l|c|c|c|c|c|}
\hline \multicolumn{1}{|c|}{ Statement } & SD=1 & $\mathbf{D = 2}$ & $\mathbf{N = 3}$ & $\mathbf{A = 4}$ & SA=5 \\
\hline $\begin{array}{l}\text { 17. Social networking sites are/can be useful in } \\
\text { education. }\end{array}$ & $\begin{array}{c}1034 \\
(9.83 \%)\end{array}$ & $\begin{array}{c}1309 \\
(12.45 \%)\end{array}$ & $\begin{array}{c}3146 \\
(29.92 \%)\end{array}$ & $\begin{array}{c}3256 \\
(30.96 \%)\end{array}$ & $\begin{array}{c}1771 \\
(16.84 \%)\end{array}$ \\
\hline $\begin{array}{l}\text { 18. The role of social networking sites will } \\
\text { increase. }\end{array}$ & $\begin{array}{c}715 \\
(6.81 \%)\end{array}$ & $\begin{array}{c}748 \\
(7.12 \%)\end{array}$ & $\begin{array}{c}2057 \\
(19.58 \%)\end{array}$ & $\begin{array}{c}3839 \\
(36.54 \%)\end{array}$ & $\begin{array}{c}3146 \\
(29.95 \%)\end{array}$ \\
\hline
\end{tabular}

Table 7. Use of social networking for educational purposes in general according to answers on Statement $19(A=4$ and $S A=5)$

\begin{tabular}{|l|c|c|c|c|c|}
\hline \multicolumn{1}{|c|}{ Statement } & SD=1 & D=2 & N=3 & A=4 & SA=5 \\
\hline $\begin{array}{l}\text { 17. Social networking sites are/can be useful in } \\
\text { education. }\end{array}$ & $\begin{array}{c}88 \\
(1.53 \%)\end{array}$ & $\begin{array}{c}242 \\
(4.20 \%)\end{array}$ & $\begin{array}{c}605 \\
(10.49 \%)\end{array}$ & $\begin{array}{c}2519 \\
(43.70 \%)\end{array}$ & $\begin{array}{c}2310 \\
(40.08 \%)\end{array}$ \\
\hline $\begin{array}{l}\text { 18. The role of social networking sites will } \\
\text { increase. }\end{array}$ & $\begin{array}{c}121 \\
(2.10 \%)\end{array}$ & $\begin{array}{c}121 \\
(2.10 \%)\end{array}$ & $\begin{array}{c}473 \\
(8.20 \%)\end{array}$ & $\begin{array}{c}2200 \\
(38.17 \%)\end{array}$ & $\begin{array}{c}2849 \\
(49.43 \%)\end{array}$ \\
\hline
\end{tabular}




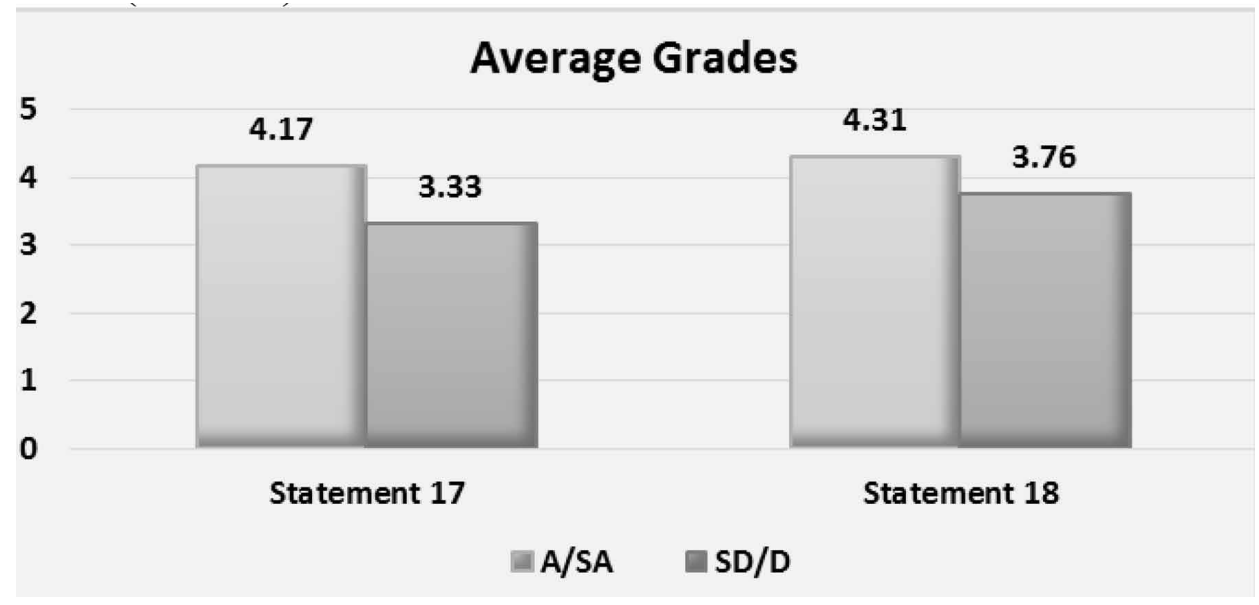

\section{Analysis According to the Continent Where Teachers Work (Answer to Research Question RQ4)}

It was necessary to make a detailed analysis of the answers to all statements according to the continent where the surveyed teachers are located, to establish the extent to which their attitude towards the use of social networking in education depends on their location. Table 8 presents the average scores given by teachers from the sixth continents. The analysis of the answers shows that the surveyed teachers from all countries do not use social networking sites in their teaching practice as a whole (see average scores on Statement 8-15). Teachers from Asia stated that they use social networking sites for communication, consultation and discussions with students (an average score 3.13 to Statement 8 and 3.12 to Statement 9). Also, they are the most active in groups interested in the use of social networking for educational purposes (an average score 3.17 to Statements 12), sharing of research interests (the highest average score to Statement 13). Teachers from Asia have the most positive attitude towards the statement that the use of social networking sites in education has a positive effect on student achievements (an average score above 3 to Statements 14). Teachers from Africa are most positive towards the statement that social networking sites increase the interest and involvement of students in the training, followed by teachers from Asia (an average score above 3 to Statement 15). Most teachers believe that the use of social networking in education can have a positive effect and their role in education will increase - only teachers from Australia are skeptical to this statement. Teachers from all countries gave average scores above 3 to Statement 18 and Statement 19. Despite the answers and teachers' strong belief in the positive effects and role of social networking, only teachers from Asia, North America and South America participate in research related to the use of social networking for educational purposes (an average score above 3 to Statement 19).

Figure 9 presents the average scores of all statements in Section 2 and Section 3 given by the surveyed teachers calculated according to the continent where they are located. Average scores are presented in parentheses - the first number is the average score on statements in Section 2 and the second number is the average score on statements in Section 3. The map clearly shows that teachers do not use social networking sites in their teaching practice now - only teachers from Asia have a positive attitude towards the use of social networking sites in teaching practice (an average score 3.14 on Section 2). All teachers think that in general the use of social networking sites can be useful for education and the educational role of the social networks will increase in the coming years (an average score above 3 on Section 3). 
Table 8. Average scores by continents

\begin{tabular}{|c|c|c|c|c|c|c|}
\hline Statement & Africa & Asia & Australia & Europe & $\begin{array}{c}\text { North } \\
\text { America }\end{array}$ & $\begin{array}{c}\text { South } \\
\text { America }\end{array}$ \\
\hline $\begin{array}{l}\text { 8. You often use social networking sites for } \\
\text { communication and consultation with your } \\
\text { students. }\end{array}$ & 3.07 & 3.13 & 1.88 & 2.71 & 2.28 & 2.94 \\
\hline $\begin{array}{l}\text { 9. You participate in social networking group/ } \\
\text { groups with your students for information } \\
\text { sharing and discussions on the courses. }\end{array}$ & 2.82 & 3.12 & 1.75 & 2.49 & 2.15 & 2.61 \\
\hline $\begin{array}{l}\text { 10. You participate in social networking group/ } \\
\text { groups with your students for organization of } \\
\text { the courses. }\end{array}$ & 2.59 & 2.94 & 1.75 & 2.40 & 2.03 & 2.39 \\
\hline $\begin{array}{l}\text { 11. You use social networking sites during } \\
\text { lessons in order to increase students' } \\
\text { involvement and to keep track of their reactions. }\end{array}$ & 2.39 & 2.68 & 1.63 & 2.00 & 1.98 & 2.28 \\
\hline $\begin{array}{l}\text { 12. You participate in online group/groups } \\
\text { interested in the use of social networking for } \\
\text { educational purposes. }\end{array}$ & 2.84 & 3.17 & 2.00 & 2.58 & 2.45 & 2.94 \\
\hline $\begin{array}{l}\text { 13. You have a public profile in some social } \\
\text { networking sites to share your research interests } \\
\text { and to connect with a wide range of people with } \\
\text { similar preferences. }\end{array}$ & 3.30 & 3.67 & 3.25 & 3.50 & 3.12 & 3.33 \\
\hline $\begin{array}{l}\text { 14. The use of social networking sites in your } \\
\text { teaching practice has a positive effect on student } \\
\text { achievements. }\end{array}$ & 3.13 & 3.22 & 2.00 & 2.73 & 2.55 & 2.78 \\
\hline $\begin{array}{l}\text { 15. The use of social networking sites in your } \\
\text { teaching practice increases the involvement and } \\
\text { interest of students in the training. }\end{array}$ & 3.41 & 3.22 & 2.00 & 2.73 & 2.55 & 2.78 \\
\hline $\begin{array}{l}\text { 17. Social networking sites are/can be useful in } \\
\text { education. }\end{array}$ & 3.97 & 3.82 & 2.88 & 3.62 & 3.60 & 4.44 \\
\hline $\begin{array}{l}\text { 18. The role of social networking sites will } \\
\text { increase. }\end{array}$ & 4.05 & 3.99 & 3.25 & 3.92 & 3.98 & 4.33 \\
\hline $\begin{array}{l}\text { 19. You participate in research related to the use } \\
\text { of social networking sites in education. }\end{array}$ & 3.00 & 3.14 & 2.88 & 2.40 & 2.39 & 3.17 \\
\hline
\end{tabular}

\section{CONCLUSION}

The study gives a clear answer to the research questions - what is the extent to which teachers from different countries all over the world use social networking sites in their teaching practice for different purposes and what is their attitude towards the use of social networking in education in general. The survey results show that teachers do not use social networking for educational purposes in their teaching practice today (an average score 2.58 on the eight statements from Section 2 of the questionnaire). It is natural that teachers who participate in groups interested in the use of social networking sites for educational purposes gave higher average scores of all statements in Section 2 (above 3) than teachers who do not participate in such groups. The average scores on all statements in Section 2 and Section 3 given by the surveyed teachers calculated according to the continent where they are located clearly shows that teachers' attitude towards the use of social networking for educational purposes depends on the continent where teachers are located. Although most surveyed teachers do not use social networking sites in their teaching practice now, they agree that the educational role of the social networks will increase in the coming years. Teachers from all continents believe that in general social 
Figure 9. Average scores on statements according to continent (Adopted form https://mapchart.net)

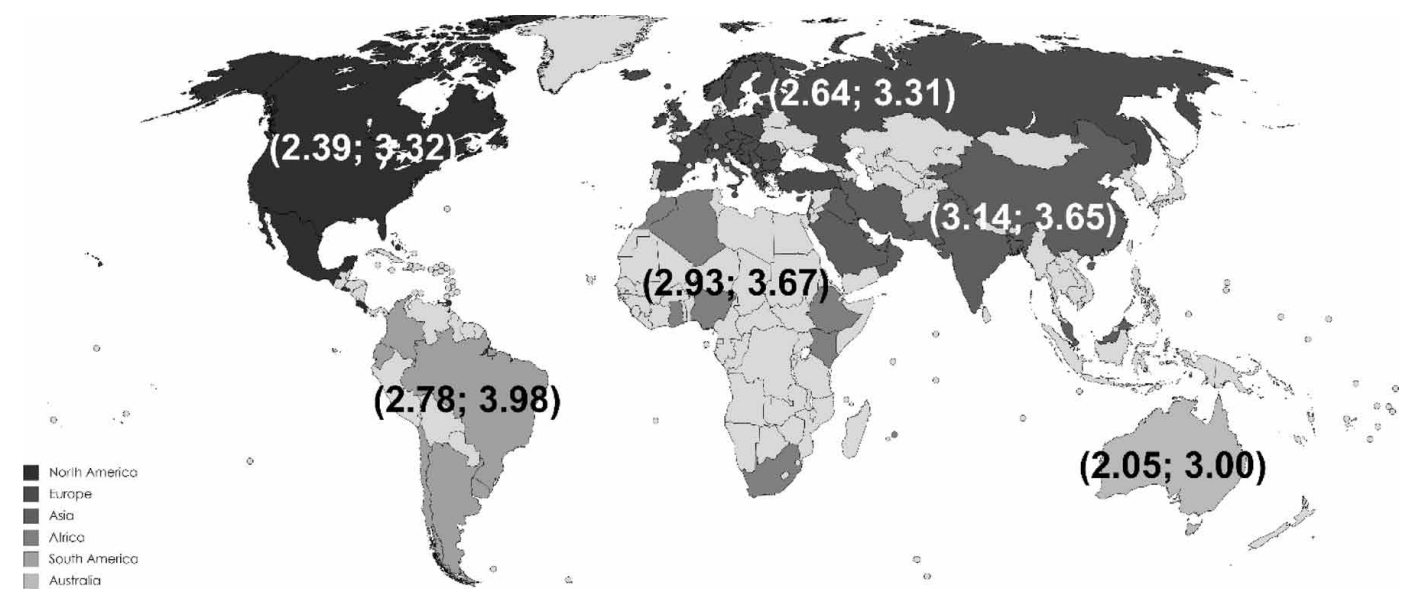

networking sites can be useful for education (an average score 3.38 on the three statements from Section 3 of the questionnaire). The negative attitude of teachers today is related to the fact that not all of them are well informed about social networking and a significant small part of them participate in research related to the opportunities for the use of social networking in education. Teachers who have a positive attitude towards the use of social networking for educational purposes believe that their use is quite beneficial if the networking site is created for educational purposes only and if the students are properly targeted to the use of the social networks and have clear guidelines. They believe that if social networking if used wisely and properly, it can enhance the learning experience and students' ability to collaborate with others. They think that social networks are one of the channels they can use to communicate effectively with students. For them, social networking can be a useful way of creating a sense of community and sharing resources, organizing and motivating students, as well as useful for research networking and execution. Furthermore, teachers stated that social networking can create interaction and increase the knowledge of students (especially in language teaching). Some teachers also think that opportunities for research, interaction and collaboration online can play a significant impact on students' achievements and learning. Teachers who do not use actively social networking for organizational/teaching activities today think that all this possibly will change in the next years with new students (with new social media behaviour) coming in.

The results show how teachers use social networking sites to meet students' needs and to modernize educational approaches. The results are useful for teachers in higher education and give them the opportunity to see how their colleagues use social media and ideas for implementation in their own academic practice.

The presented study has some limitations. For instance, the response rate for specific countries may have influenced the truth of the findings and this is a factor that can be explored in the future. Another development option is to analyze the response rate on the basis of Internet access and accessibility to some of the types of social media in different countries. An interest for researchers working in the field will be to deepen the analysis of the collected data by applying metrics for qualitative analysis (e.g. median for central tendency and interquartile range for variation) and non-parametric tests (e.g. chi-squared test, Mann-Whitney test, Wilcoxon signed-rank test, or Kruskal-Wallis test) which are often used in the analysis of Likert scale data. 


\section{ACKNOWLEDGMENT}

The paper is supported within the National Scientific Program "Young scientists and Post-doctoral students" in accordance with Appendix No. 11 of Council of Ministers Decision No. 577 of 17 August 2018. 


\section{REFERENCES}

Abu-Shanab, E., \& Al-Tarawneh, H. (2015). The Influence of Social Networks on High School Students' Performance. International Journal of Web-Based Learning and Teaching Technologies, 10(2), 49-59. doi:10.4018/IJWLTT.2015040104

Acharya, V., Patel, Ad., \& Jethava, S. (2013). A Survey on Social Networking to Enhance the Teaching and Learning Process. International Journal of Advanced Research in Computer Science and Software Engineering, $3(6), 528-531$.

Arquero, J., \& Romero-Frías, E. (2013). Using social network sites in Higher Education: An experience in business studies. Innovations in Education and Teaching International, 50(3), 238-249. doi:10.1080/147032 97.2012.760772

Aviles, M., \& Eastman, J. (2012). Utilizing technology effectively to improve millennials' educational performance. Journal of International Education in Business, 5(2), 96-113. doi:10.1108/18363261211281726

Doneva, R., \& Gaftandzhieva, S. (2017). Social Media in Bulgarian Higher Education: An Exploratory Survey International Journal of Human Capital and Information Technology Professionals, 8(4), 67-83. doi:10.4018/ IJHCITP.2017100106

edWeb. (2009) A Survey of K-12 Educators on Social Networking and Content-Sharing Tools. Retrieved from https://www.edweb.net/fimages/op/K12Survey.pdf

Faculty Focus. (2011). Social Media Usage Trends Among Higher Education Faculty. Retrieved from https:// www.facultyfocus.com/free-reports/social-media-usage-trends-among-higher-education-faculty/

Golubić, K. (2017). The Role of Social Networks in the Presentation of Croatian Higher Education Institutions (PhD Thesis). URN:NBN. https://urn.nsk.hr/urn:nbn:hr:102:527811

Golubić, K, \& Lasić-Lazić, J. (2012) Analysis of On-line Survey about Need for Presence of Higher Education Institutions on Social Networks: A Step towards Creation of Communication Strategy. Journal of Computing and Information Technology - CIT, 20(3), 189-194.

Hendee, C. (2014). Teachers have mixed feelings on using social media in classrooms. Retrieved from https:// www.bizjournals.com/denver/news/2014/02/11/teachers-have-mixed-feelings-on-using.html

Junco, R., Elavsky, C., \& Heiberger, G. (2013). Putting twitter to the test: Assessing outcomes for student collaboration, engagement and success. British Journal of Educational Technology, 44(2), 273-287.

Kolan, B., \& Dzandza, P. (2018). Effect of Social Media on Academic Performance of Students in Ghanaian Universities: A Case Study of University of Ghana, Legon. Library Philosophy and Practice (e-journal), 1637.

Kropf, D. (2013). Connectivism: 21st Century's New Learning Theory. European Journal of Open, Distance and e-Learning, 16(2), 13-24.

Mardikyan, S., \& Bozanta, A. (2017). The effects of social media use on collaborative learning: A case of Turkey. Turkish Online Journal of Distance Education, 18(1), 96-110.

Moran, M., Seaman, J., \& Tinti-Kane, H. (2011). Teaching, Learning, and Sharing: How Today's Higher Education Faculty Use Social Media. Pearson Learning Solutions and Babson Survey Research Group.

Prensky, M. (2001). Digital Natives, Digital Immigrants. On the Horizon, 9(5), 1-6.

Rodriguez, J. (2011). Social media use in higher education: Key areas to consider for educators. Journal of Online Learning and Teaching, 7(4), 539-550.

Rothkrantz, L. (2015). How Social Media Facilitate Learning Communities and Peer Groups around MOOCS. International Journal of Human Capital and Information Technology Professionals, 6(1), 1-13.

Rutherford, C. (2010). Using online social media to support preservice student engagement. Journal of Online Learning and Teaching, 6(4), 703-711.

Seaman, J., \& Tinti-Kane, H. (2013). Social Media for teaching and learning. Pearson Learning Solutions. 
Somova, E. (2014). An attempt for using collaborative work of students as an approach for learning and evaluation. Proceedings of V National Conference "E-learning in higher education", 188-193.

Statista. (2018). Most popular social networks worldwide as of January 2018, ranked by number of active users (in millions). Retrieved form https://www.statista.com/statistics/272014/global-social-networks-rankedby-number-of-users/

Voorn, R., \& Kommers, P. (2013). Social media and higher education: Introversion and collaborative learning from the student's perspective. International Journal of Social Media and Interactive Learning Environments, $1(1), 59-71$.

Wang, Q., Woo, H., Quek, C., Yang, Y., \& Liu, M. (2011). Using the Facebook group as learning management system: An exploratory study. British Journal of Educational Technology, 43(3), 428-438.

Zanamwe, N., Rupere, T., \& Kufandirimbwa, O. (2013). Use of Social Networking Technologies in Higher Education in Zimbabwe: A learners' perspective. International Journal of Computer and Information Technology, 2(1), 8-18.

Zancanaro, A., \& Domingues, M. (2018). Massive open online courses (MOOC) for teaching Portuguese for foreigners. Turkish Online Journal of Distance Education-TOJDE, 19(2), 4-20. 


\section{APPENDIX}

\section{Survey}

Section 1. Personal Information for Participant

1. What is your gender? $\bigcirc$ male $\bigcirc$ female

2. How old are you? $\bigcirc$ below $25 \bigcirc 25-34 \bigcirc 35-44 \bigcirc 45-54 \bigcirc$ above 55

3. What is your scientific degree? $\bigcirc \mathrm{PhD} \bigcirc \mathrm{D}$. Sc. OOther

4. What is your academic position? OAssistant OAssistant Professor OAssociate Professor OProfessor OOther

5. In which university/institute/academy are you working?

6. In which country are you working?

7. Are you well informed about social networking (e.g. Facebook, Twitter, Google+, Bebo, Myspace, LinkedIn, etc.)? OYes OYes/No ONo

Please, give your opinion on the statement from Section II and Section III by expressing your agreement / disagreement in the following five-point scale: 1. Strongly disagree; 2. Disagree; 3. Neutral; 4. Agree; 5. Strongly agree.

\section{Section 2. Opinion on the Use of Social Networks in Teaching Practice}

8. You often use social networking sites for communication and consultation with your students. O1. Strongly disagree O2. Disagree $\bigcirc 3$. Neutral $\bigcirc$. Agree $\bigcirc 5$. Strongly agree.

9. You participate in social networking group/groups with your students for information sharing and discussions on the courses.

○1. Strongly disagree $\bigcirc 2$. Disagree $\bigcirc 3$. Neutral $\bigcirc 4$. Agree $\bigcirc 5$. Strongly agree.

10. You participate in social networking group/groups with your students for organization of the courses.

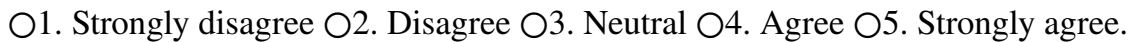

11. You use social networking sites during lessons in order to increase students' involvement and to keep track of their reactions.

O1. Strongly disagree $\bigcirc 2$. Disagree $\bigcirc 3$. Neutral $\bigcirc$. Agree $\bigcirc 5$. Strongly agree.

12. You participate in online group/groups interested in the use of social networking for educational purposes.

○1. Strongly disagree $\bigcirc 2$. Disagree $\bigcirc 3$. Neutral ○4. Agree $\bigcirc 5$. Strongly agree.

13. You have a public profile in some social networking sites to share your research interests and to connect with a wide range of people with similar preferences.

O1. Strongly disagree O2. Disagree $\bigcirc 3$. Neutral $\bigcirc$. Agree $\bigcirc 5$. Strongly agree.

14. The use of social networking sites in your teaching practice has a positive effect on student achievements.

O1. Strongly disagree O2. Disagree $\bigcirc 3$. Neutral $\bigcirc$. Agree $\bigcirc 5$. Strongly agree.

15. The use of social networking sites in your teaching practice increases the involvement and interest of students in the training.

O1. Strongly disagree O2. Disagree 03 . Neutral $\bigcirc$. Agree $\bigcirc$ 5. Strongly agree.

16. You use social networking sites in your teaching practice in ways other than those stated above - please specify. 
Section 3. Opinion on the Use of Social Networking for Educational Purposes in General

17. Social networking sites are/can be useful in education.

○1. Strongly disagree $\bigcirc 2$. Disagree $\bigcirc 3$. Neutral $\bigcirc$. Agree $\bigcirc 5$. Strongly agree.

18. The role of social networking sites will increase. O1. Strongly disagree $\bigcirc 2$. Disagree $\bigcirc 3$. Neutral $\bigcirc 4$. Agree $\bigcirc 5$. Strongly agree.

19. You participate in researches related to the use of social networking sites in education. $\bigcirc 1$. Strongly disagree $\bigcirc 2$. Disagree $\bigcirc 3$. Neutral $\bigcirc 4$. Agree $\bigcirc 5$. Strongly agree.

20. You think that the use of social networking sites for educational purposes has a rather negative effect - specify.

Silvia Gaftandzhieva, PhD - Associate Professor at the University of Plovdiv "Paisii Hilendarski", Faculty of Mathematics and Informatics, Department of Computer Science. Her research areas include e-learning and distance learning, automated evaluation of quality in higher education, distance learning. She is an author of 80 scientific publications in the field of quality assurance (of HE, e-Learning, Projects, etc.), e-Learning, m-Learning, etc. with over 160 citations.

Rositsa Doneva, PhD - Professor at the University of Plovdiv "Paisii Hilendarski", ECIT Department. She has led/ taken part in more than 50 national and international projects in the areas of computer science, electronic and distance learning, applications of IT in education, etc. Prof. Doneva is the author of over 110 scientific publications in the field of Intelligent Systems, Conceptual Modelling, quality assurance (of HE, e-Learning, Projects, etc.), OOP, e-Learning, m-Learning, etc. and 40 textbooks and learning materials with over 300 citations. 